jobless cannot be acceptable. Higher productivity can well lead to unemployment, so it is most important that the aim, particularly within the rural sector, should not be for a mighty technological revolution which releases vast numbers of agricultural workers to flock to cities incapable of receiving them. The abundant manpower resources of many developing countries have to be handled with the greatest of care. One Bangladeshi contribution put this very succintly: "in most cases our object is to upgrade simple rural technology to a slightly higher level of sophistication which improves the quality of life for the workers and creates more job opportunities." The emphasis, then, is on modest aims and on evolutionary development. In a notably thoughtful contribution, Dr H. Harada, Deputy Assistant Director-General for Science at Unesco, drew attention to the need to accept a slow and deliberate pace, in which a nation is at pains to develop science ahead of technology.

So what comes from such a conference? A final docu- ment, necessarily general, of course. But maybe the germs of something more substantial. Numerous participants, while recognising that no New International Economic Order will come about without a correspondingly new national order, note nonetheless that there is enormous scope for international research centres to cope with developing world problems. Few of these problems respect national frontiers, nor are they such that questions of commercial secrecy should be involved. If there can be an International Centre for Theoretical Physics, specifically aimed to assist developing countries, is there not some sense in international, maybe regional centres on other scientific matters perhaps of a more immediate concern to development? A few exist already, of course, notably through the Canadian initiative of the International Development Research Centre, but there was little doubt in people's minds at Algiers that there was scope for more. As David Dickson reports on the following page this mood now seems widespread.

\title{
Multinationals and development
}

Multinational corporations often come under criticism for their involvement in the developing world. But, argues Lewis Branscomb, Vice President and Chief Scientist of IBM, multinationals make major contributions to indigenous development.

The United Nations Conference on Science and Technology for Development (UNCSTD) will look at the urgent need for indigenous capabilities in both developed and developing nations to mobilise science and technology in the cause of human problems. Poorer nations are understandably impatient with the slow and expensive process of institution building out of which emerged the education, research and industrial enterprises of the industrial democracies. But without the capacity to absorb, adapt and exploit technical knowledge, no amount of documented knowledge, patent licences or computer access will produce the economic results that are needed. How can this capacity be built?

National assistance agencies, international banks and private foundations can do a lot more than they have. Technical assistance programmes should be separated from security and capital assistance. Every prosperous nation has to find its own way to focus the energies of its universities and private sector establishments on institution building in cooperation with less developed countries. President Carter has made a farsighted proposal in his speech in Venezuela, proposing a government-sponsored foundation for technical cooperation to deal with this long-term need of the developing world.

Technical cooperation in education and research can look after many basic human needs, but industrial capability is only built up very slowly in this way. What is a more direct route? The fastest way to transfer technical capability from one nation to another is by exchange of the people with skills and experience, tools and procedures, and (when required) their financial resources and foreign market access. American industrial technology was built by direct foreign investment by European firms in Victorian times. Research was little known in 19th century American universities; the nation's industry was craft-oriented. Most of the population was in agriculture, which based its productivity more on the expanse of unexploited fertile land than on the cropping technology of Europe.

Why then are today's industrial enterprises which are engaged in technologically-sophisticated operations in many countries (the "multinationals") so often regarded as part of the problem, when in fact they are a part of the solution?

When a responsible, modern multinational starts a business operation in a host developing country, it contributes to indigenous technical and managerial development in many ways. For example:

- By hiring and training host-country nationals for all levels of employment in the national subsidiary. Education and experience in industrial operations is gained in the community and is made successful under local conditions. - Through technical cooperation of the multinational's local manufacturing plants with its plants and laboratories in other nations, a broad base of technical support is available in the event of technical difficulties.

- By obtaining materials, parts and assembly from local suppliers (IBM has 80,000 such vendors worldwide), a great deal of technological knowledge and experience is transferred, as the local company of the multinational works with each vendor to assure quality control of the product.

- As local skills develop and local markets justify expanded investment, more complex products can be undertaken by national subsidiaries and access to international markets expanded. In this way multinationals make important contributions to the balance of trade in many developing countries.

- Many products, such as communications equipment, trucks, machine tools and computers, not only contribute to national wealth directly but have large secondary benefits because their use in other sectors can increase productivity in the economy as a whole.

Sovereign nations must certainly look after the interests of their citizens by determining the rules regarding investments of skills and money within their borders. It is important that the leaders of those countries avail themselves of technical advice from those with industrial experience, to ensure that policies driven by economic objectives take into account technological realities. Transferring technology, even within the component parts of a single American or European enterprise, is not easy and requires time, training and extra expense. But above all it calls for a cooperative attitude by all the participants.

Let us hope that this is the outcome of the 1979 conference. 